\title{
Performance and Genetic Variability of Okra (Abelmoschus esculentus (L.) Moench) Genotypes in Ethiopia for Agromorphology and Biochemical Traits
}

\author{
Jemal Mohammed (D, ${ }^{1}$ Wassu Mohammed, ${ }^{2}$ and Eleni Shiferaw ${ }^{1}$ \\ ${ }^{1}$ Crop and Horticulture Biodiversity Directorate, Ethiopian Biodiversity Institute, Addis Ababa, Ethiopia \\ ${ }^{2}$ School of Plant Science, Haramaya University, Dire Dawa, Ethiopia \\ Correspondence should be addressed to Jemal Mohammed; jemalm781@gmail.com
}

Received 22 January 2021; Accepted 4 January 2022; Published 27 January 2022

Academic Editor: Amelia Salimonti

Copyright (c) 2022 Jemal Mohammed et al. This is an open access article distributed under the Creative Commons Attribution License, which permits unrestricted use, distribution, and reproduction in any medium, provided the original work is properly cited.

\begin{abstract}
No research has been done to assess the genetic diversity of Okra (Abelmoschus esculentus) genotypes in Ethiopia based on the combination of agromorphology and biochemical traits of the crop. Such an assessment would assist in the development of high fruit yield and nutritionally good cultivars. Therefore, 36 okra genotypes were evaluated for 29 agromorphological and biochemical traits at the Melkassa Agricultural Research Center (Ethiopia) during the 2018 main rainy season, using a $6 \times 6$ simple lattice design. Analysis of variance showed significant differences among genotypes for all the studied traits, except number of flower epicalyxes and fruit diameter. Genotypic coefficients of variation and phenotypic coefficient of variation were high for number of branches, internode length, fresh fruit weight, number of mature pods, fruit yield per plant, fruit yield per hectare, seed yield per plant, seed yield per hectare, and seed protein content. Heritability values ranged between 33.63 and $99.81 \%$, while the genetic advance as percentage of mean ranged between 4.29 and $95.45 \%$. High broad sense heritability was coupled with high GAM for plant height, branch, internod length, fruit length, panicle length, fresh fruit weight, number of fruits per plant, number of mature pods, seed yield per plant, seed yield per hectare, and fibre and protein content. In conclusion, this study showed the presence of genetic variation among genotypes for fruit yield, seed yield, and nutritional content, indicating the potential success of developing okra varieties for high fruit yielding and good nutritional content.
\end{abstract}

\section{Introduction}

Okra [Abelmoschus esculentus (L.) Moench] is one of the most widely known and utilized species of the family Malvaceae [1]. Okra is native to North Eastern Africa in the area of Ethiopia and Sudan [2]. The plant is also cultivated in tropical, subtropical, and warm temperate regions around the world [3] and distributed throughout the world [4].

Okra has nutritional [5], economical, and industrial values [6]. The nutritive value of okra comprises carbohydrate, protein, fat, iron, calcium, fibre, thiamine, nicotinamide, riboflavin, and ascorbic acid [7]. The dried seeds can be used to prepare vegetable curds or roasted and ground and used as a coffee additive or substitute [8].
Characterization of okra has great importance for current and future genetic improvement programs of the crop [9].

Proper management of crop diversity can produce a permanent gain in the performance of plant, while high heritability of the traits gives a better opportunity for breeders to select directly for the traits of interest [10]. In all crops, knowledge of genetic diversity is a prerequisite to develop varieties or to identify parental lines to use in combination breeding [11]. However, there is no complete data on production area and productivity of okra in Ethiopia, although it is a traditional crop in South Western, Western, and North Western part of the country. The crop has been considered a minor crop and has not been given research attention [12]. The first improved variety 
(Bamya-Humera) for tender fruit yield has been recommended for cultivation recently in 2016 [13]. Moreover, there is no research conducted in Ethiopia on the oil content of okra seed. Therefore, the utilization of the crop in Ethiopia demands the assessment of the genetic diversity of okra germplasms for agromorphology and biochemical traits. Also, prior information on biochemical content or nutrient compositions such as protein, fibre, and ash is necessary for proper utilization of the crop. Yet, no attempt has been made to assess the diversity of okra in Ethiopia based on the combination of agromorphology traits and biochemical contents of the crop.

Therefore, the aim of this research was to evaluate the performance of genotypes for fruit yield and nutritional content of the seed and estimate the variability of Ethiopian landrace okra genotype along with exotic commercial varieties based on morphology and biochemical traits.

\section{Materials and Methods}

2.1. Description of the Study Site. The experiment was conducted at the Melkassa Agriculture Research Center, Ethiopia, during the 2018 main cropping season (rainy season). Melkassa is located at $8^{\circ} 24^{\prime} 59.20^{\prime \prime} \mathrm{N}$ latitude and $39^{\circ} 19^{\prime} 15.19^{\prime \prime} \mathrm{E}$, with an altitude of $1548 \mathrm{~m}$ above sea level. The area is characterized by low and erratic rainfall, with a mean annual rainfall of $796 \mathrm{~mm}$ and peaks in July and August. The dominant soil type of the centre is andosol of volcanic origin with $\mathrm{PH}$ that ranges from 7 to 8.2 . The mean annual temperature is $21.2^{\circ} \mathrm{C}$ with a minimum of $14^{\circ} \mathrm{C}$ and a maximum of $28.4^{\circ} \mathrm{C}$ [14]. The biochemical contents of the seeds were determined at the Ethiopian Biodiversity Institute Nutrition Laboratory (total ash and crude fat), Debre Zeit Agricultural Research Center (crude fibre), and Melkassa Agriculture Research Center (total protein).

2.2. Experimental Materials and Design. Thirty-six okra genotypes were used. Twenty-four landrace accessions collected by the Ethiopian Biodiversity Institute from different okra growing regions of Ethiopia, three genotypes from Humera Agriculture Research Center, and nine exotic commercial varieties (eight from India and one from USA) were included (Table 1 ). The genotypes were planted using a $6 \times 6$ simple lattice design with two replications. Three seeds per hill were sown and thinned to one plant per hill when plants reached 3-4 leaves' stage.

2.3. Data Collection. Data were collected for phenology traits (days to $50 \%$ emergence, days to first flowering, days to $50 \%$ flowering, and days to $90 \%$ maturity) growth and yield related traits (plant height, stem diameter, number of primary branches per stem, number of internodes, internodes length, leaf length, leaf width, number of flower epicalyxes, peduncle length, fruit length, fruit diameter, average fruit weight, number of tender fruits per plant, number of mature pods per plant, number of ridges on fruit, fruit yield per plant, fruit yield per hectare, number of seeds per pod, hundred-seed weight, seed yield per plant, and seed yield per hectare), biochemical content (total ash, total fat, crude fibre, and total protein) and qualitative traits (plant growth habit, flower color, leaf color, leaf petiole color, immature fruit color, stem color, position of fruits on the main stem, fruit pubescence, and leaf pubescence). Data of quantitative and qualitative traits were recorded according to the International Plant Genetic Resources Institute [15] (IPGRI, 1991) descriptor list developed for okra.

Total ash was determined at Ethiopian Biodiversity Institute nutrition laboratory following the method of [16] based on a wet weight basis. Crude fat content of okra seed was determined at Ethiopian Biodiversity Institute nutrition laboratory following the procedure of [16]. The fat content was determined based on wet weight. Crude fibre was determined at Debre Zeit Agricultural Research Center nutrition laboratory following nonenzymatic gravimetric method [16]. Total protein contents were determined following the Kjeldahl method of protein determination and the procedure of [16] at Melkassa Agriculture Research Center. The biochemical traits were analyzed following a completely randomized design (CRD) procedure.

2.4. Analysis of Variance. The quantitative data were subjected to analysis of variance (ANOVA) and computed with SAS statistical software (9.0) [17]. The quantitative data were collected in a simple lattice (partially balanced or incomplete block) design and analysis of variance was computed considering the general linear model. The qualitative data were presented in percentage. The mean performance of genotypes comparison was done following the significance of mean squares using Duncan's Multiple Range Test (DMRT) at $P<0.05$. The traits that exhibited significant mean squares in general ANOVA were further subjected to genetic analyses. Based on mean square expectations from the analysis of variance, phenotypic and genotypic coefficients of variations, heritability, and genetic advance were calculated.

2.5. Estimate of Genetic Variability Components. The phenotypic and genotypic variabilities of each quantitative trait were estimated as phenotypic and genotypic variances and coefficients of variation. The genotypic variance was estimated according to the method suggested by [18] considering mean square expectations from the analysis of variance.

2.6. Heritability and Genetic Advance. Broad sense heritability values were estimated using the formula adopted by [19].

2.7. Expected Genetic Advance under Selection. Genetic advance in absolute unit (GA) and percent of the mean (GAM), assuming selection of superior $5 \%$ of the genotypes, were estimated in accordance with the methods illustrated by [20]. 


\section{Results and Discussion}

\subsection{Analysis of Variance and Mean Performance of Genotypes}

3.1.1. Phenology and Growth Traits. The results of the analysis of variance for 13 phenology and growth traits indicated the presence of significant differences among the 36 okra genotypes, and genotypes had nonsignificant difference for number of flower epicalyxes. Reference [21] also characterized okra genotypes collected from BenishangulGumuz reginal state of Ethiopia and reported that there were no significant differences in numbers of flower epicalyxes among the studied genotypes.

The presence of significant variations among genotypes will allow the breeders to identify genotypes for varied crop maturity and plant growth traits. The genotypes had a range of 7 to 8 days to $50 \%$ emergence, 50 to 61.5 days to first flowering, 54.5 to 66.5 and 74 to 87 days to $50 \%$ flowering and maturity, respectively (Supplementary Materials Table 1). The three genotypes 29407,242440 , and 240584 showed delayed days to first flowering. Also, 29407, 240584, and 242439 had delayed days to 50\% flowering and 29407, 240584,242439 , and 242450 had delayed days to maturity. Meanwhile, the released varieties (Bamya-Humera) and introduced commercial variety, Clemson Spineless, as well as Humera 1 genotype, were early to flowering and maturity. Having such a wide variation of phenology traits would help to select or develop early maturing okra genotypes which can escape drought and can be cultivated in drought prone areas of Ethiopia. Similar results are reported by [12] that observed 37 to 65 and 50 to 101 days to first flowering and maturity, respectively, in 25 okra genotypes collected from Southwestern Ethiopia. Reference [22] also observed 53 to 62 and 84 to 104 days to first flowering and maturity, respectively, in genotypes collected from three geographic regions of Ethiopia and two introduced okra varieties evaluated at Werer Agricultural Research Center, Ethiopia.

The plant height of genotypes was in the range between 70.5 and $162.03 \mathrm{~cm}$, with a mean of $114.2 \mathrm{~cm}$ (Supplementary Materials Table 2). The genotype had an average stem diameter of $1.76 \mathrm{~cm}$, which varied from 1.26 to $2.34 \mathrm{~cm}$. The highest mean values for stem diameter $(2.34 \mathrm{~cm})$ and plant height $(162.03 \mathrm{~cm})$ were measured from 240581 to 242450 , respectively. Reference [23] noted that okra genotypes having high dry biomass can be used as livestock feed during the dry season. Therefore, these tallest genotypes can be selected for farmers for their feed for livestock besides their fruit and grain yield. Reference [24] Indicated that okra is an annual plant with robust stem and erect growth with variable branching that grows to 0.5 to $4.0 \mathrm{~m}$ in height.

A wide range of variation was observed among genotypes for numbers of branches, number of internodes, and internodes length in the ranges between 0.7 and 4.15, between 12.21 and 20.93, and between 3 and $10.5 \mathrm{~cm}$, respectively. The genotypes overall mean values were $2.23 \mathrm{~cm}, 14.83 \mathrm{~cm}$, and $5.33 \mathrm{~cm}$ for number of branches, number of internodes, and internodes length, respectively. The mean ranges of leaf length and leaf width of genotypes varied from 10.5 to $19 \mathrm{~cm}$ and from 14.84 to $27.1 \mathrm{~cm}$, respectively. The genotypes had overall mean values of $14.41 \mathrm{~cm}$ and $20.18 \mathrm{~cm}$ for leaf length and leaf width, respectively. Both the longest leaf and widest leaf were observed from 29407. The highest number of branches (4.15) and internodes length $(10.5 \mathrm{~cm})$ were registered form 240608 and Bamya-Humera, respectively. Those genotypes having the largest leaf and widest leaf could be selected due to the fact that leaves are the primary source of photosynthesis to produce better yield and yield related traits.

3.1.2. Fruit Yield and Yield Components. The genotypes exhibited highly significant $(P<0.01)$ difference for fruit length, weight, number of mature pods, number of fruits per plant, fruit yield per plant, fruit yield per hectare, seed per pod, hundred-seed weight, seed yield per plant, and seed yield per hectare. However, the genotypes exhibited a nonsignificant difference for fruit diameter. Fruit length of genotypes was in a range between 8.25 and $22.86 \mathrm{~cm}$, while number of fruit ridges was varied from 5 to 9.5 and fresh fruit weight varied from 20.82 to $62.41 \mathrm{~g}$ (Supplementary Materials Table 3). The genotypes had overall mean values of $15.45 \mathrm{~cm}$, 7.06 , and $34.77 \mathrm{~g}$ for fruit length, the number of fruit ridges, and fresh fruit weight, respectively. The genotypes 29407 and 242450 had the longest and shortest fruit lengths, respectively. These genotypes, 29407 and 242450, also had the highest and lowest fresh fruit weights, respectively. The three exotic commercial varieties (Arka Anamika, Kiran, and Pocha) had the lowest number of fruit ridges (5 to 5.6), while three genotypes collected from Ethiopia (Humera 2, 240613, and 240589) had the highest number of fruit ridges (8.35 to 9.5). The number of fruits per plant and number of mature pods of genotypes varied from 19 to 33.86 and from 3.5 to 18.75 , respectively. The genotype had average number of fresh fruits and number of mature pods of 27.4 and 9.09 , respectively. Genotypes 240612 and Bamya-Humera had the highest number of fruits per plant, while genotypes 240610 and 240612 had the highest number of mature pods. Having wide range of variation in mean values indicated the presence of high variability for these characters, thus offering greater scope for selecting desirable genotypes.

The wide variation between the performances of genotypes for number of fresh fruits and number of mature pods may be due to the frequent harvesting of immature green fruits. This may encourage the production of more flowers and fruits but not for harvesting of mature pods. Okra is generally picked at a tender stage of maturity and directly correlated with number of fruits produced per plant and yield [25]. Okra plants continue to bloom and set fruit if all pods are harvested at the proper early stage [26]. The short picking interval encouraged the plant to produce higher number of fruits per plant and long picking interval increased the fruit size and weight [27]. The present result is in agreement with two reports from Ethiopia [21, 22, 28]. A similar result had also been reported from India [29, 30]. Reference [31] also reported a similar result from Pakistan.

The immature fruit attains a length from 8 to $20 \mathrm{~cm}$ and a diameter of up to $3 \mathrm{~cm}$ or more. The size of okra fruits is related to maturity and quality because the crude fibre content of the mature biggest pods will be higher (7.78\%) than that in 
TABLE 1: Description of okra genotypes and collection origin.

\begin{tabular}{|c|c|c|c|}
\hline $\mathrm{S} / \mathrm{N}$ & Genotype & District & Geographic region \\
\hline 1 & 29407 & Kurmuk & Western Ethiopia \\
\hline 2 & 240581 & Gambela & South Western Ethiopia \\
\hline 3 & 240584 & Akobo & South Western Ethiopia \\
\hline 4 & 240589 & Abobo & South Western Ethiopia \\
\hline 5 & 240593 & Gog & South Western Ethiopia \\
\hline 6 & 240594 & Gog & South Western Ethiopia \\
\hline 7 & 240596 & Gog & South Western Ethiopia \\
\hline 8 & 240598 & Gog & South Western Ethiopia \\
\hline 9 & 240603 & Gambela & South Western Ethiopia \\
\hline 10 & 240208 & Itang & South Western Ethiopia \\
\hline 11 & 240610 & Gambela & South Western Ethiopia \\
\hline 12 & 240612 & Gambela & South Western Ethiopia \\
\hline 13 & 240613 & Gambela & South Western Ethiopia \\
\hline 14 & 240614 & Gambela & South Western Ethiopia \\
\hline 15 & 240782 & Metema & North Western Ethiopia \\
\hline 16 & 240783 & Dangur & North Western Ethiopia \\
\hline 17 & 242434 & Metekel & North Western Ethiopia \\
\hline 18 & 242436 & Asosa & Western Ethiopia \\
\hline 19 & 242438 & Asosa & Western Ethiopia \\
\hline 20 & 242439 & Asosa & Western Ethiopia \\
\hline 21 & 242440 & Asosa & Western Ethiopia \\
\hline 22 & 242442 & Asosa & Western Ethiopia \\
\hline 23 & 242446 & Asosa & Western Ethiopia \\
\hline 24 & 242450 & Asosa & Western Ethiopia \\
\hline 25 & Bamya-Humera & Humera & Northern Ethiopia \\
\hline 26 & Humera 1 & Humera & Northern Ethiopia \\
\hline 27 & Humera 2 & Humera & Northern Ethiopia \\
\hline 28 & Clemson Spineless & & USA \\
\hline 29 & SOH 701 & & India \\
\hline 30 & Dhenu & & India \\
\hline 31 & Kiran & & India \\
\hline 32 & Kraft & & India \\
\hline 33 & Pocha & & India \\
\hline 34 & MITHRA & & India \\
\hline 35 & Arka Anamika & & India \\
\hline 36 & Namdhari & & India \\
\hline
\end{tabular}

smaller sized immature fruits (2.27\%) [32]. The fruits picked at this stage have optimum fresh weight, length, and diameter and are free from thick pericarp, thus making it consumable [33]. Harvesting of medium size green fruits $(18-20 \mathrm{~cm}$ in length and $28-30 \mathrm{~g}$ in weight) has higher consumer preference and produced higher yield of okra [34]. In the present study, all genotypes had fruit length of 8.25 to $22.86 \mathrm{~cm}$ and 20 genotypes had fruit weight of 21.31 to $35.61 \mathrm{~g}$ and 16 other genotypes collected from Ethiopia had fruit weight of 35.65 to $62.41 \mathrm{~g}$. This indicated that most of the genotypes had acceptable medium fruit length and fruit weight, and the largest proportion of genotypes collected from Ethiopia with high fruit weight as compared to introduced commercial varieties might be due to genetic differences for producing heavy weight fruits. Selection of potential parents based on this preferable fruit trait would be essential in okra breeding programs to develop new cultivar in the country for subsistence agrofarmers and commercial production.

The genotypes produced 0.57 to $1.86 \mathrm{~kg}$ and 11.865 to 38.85 tons of fruit yield per plant and fruit yield ha ${ }^{-1}$ with an overall mean of $0.96 \mathrm{~kg}$ and 20.06 tons, respectively (Supplementary Materials Table 4$)$. The highest $(1.865 \mathrm{~kg} /$ plant) fruit yield per plant was obtained from 29407 (Ethiopian collection), while the lowest $(0.57 \mathrm{~kg})$ was obtained from introduced commercial variety (Pocha). Mean values of genotypes ranged from 62.62 to 128.16 for seeds per pod, from 5.32 to $8 \mathrm{~g}$ for hundred-seed weight, from 23.95 to $116.3 \mathrm{~g}$ for seed yield per plant, and from 498.9 to $2,423 \mathrm{~kg}$ for seed yield per ha ${ }^{-1}$. The highest number of seeds per pod (128.17) and hundred-seed weight $(8.0 \mathrm{~g})$ were registered from 2424446 and 240593 , respectively. The lowest and highest seed yields were obtained from 242439 and 240581, respectively. The okra collections from Ethiopia had great variation for all seed yield and seed yield related traits. This suggests the higher chance of improving fruit and seeds yield through selection among okra genotypes collected from Ethiopia to produce a high amount of edible oil and for other purposes such as seeds as a substitute for coffee and protein source.

3.1.3. Biochemical Traits. The genotypes exhibited highly significant $(P<0.01)$ difference for all biochemical contents (moisture content, total ash, crude fat, crude fibre, and total protein). Seeds moisture content and crude fibre content of 
genotypes were measured as 7.75 to $8.64 \%$ and 23.8 to $37.01 \%$, respectively, while total ash, crude fat, and total protein content were 3.82 to $4.95 \%, 13.135$ to $17.2 \%$, and 4.51 to $24.79 \%$, respectively (Supplementary Materials Table 5). The genotypes had overall mean values of $8.22,4.29$, and $15.35 \%$ for seed moisture content, total ash, and crude fat, respectively, and the overall mean values were 30.37 and $11.06 \%$ for seed total fat and protein content, respectively. The highest and lowest seeds moisture contents were recorded from 240584 and 242434, respectively. The highest seeds total ash and lowest seeds total ash were measured from 242434 and 240484, respectively. The highest mean values for crude fat, crude fibre, and total protein were measured from 240598, 240589, and 240584, respectively. The genetic variation that existed in these genotypes would assist the breeders in the selection of potential parental okra lines for the development of new okra cultivars with high nutrient content. Due to the current prevalence of malnutrition in the world, particularly in Ethiopia, Africa, breeding for higher nutritional quality crops is very important to lessen malnutrition in the country.

Reference [35] reported that whole okra grain flour had $20.5,14.73,36.9$, and $5.70 \%$ of protein, fat, fibre, and ash, respectively. Besides, [36] reported that okra whole seeds contain $24.24 \%$ of protein, $16.22 \%$ of fat, $23.43 \%$ of fibre, and $4.79 \%$ of Ash. Reference [23] reported that the crude protein content of immature fruits of okra was analyzed and varied from negligible amount (nitrogen was not detected in genotypes) to $21.45 \%$

3.2. Qualitative Characters of Okra Genotypes. This result showed that almost all genotypes had similar growth habits which are densely branched base (DBB) characters except one genotype that had densely branched over (DBO) as per [15] descriptors for okra. All genotypes showed similar flower color (red on both sides) and immature fruit color (totally green). The genotypes are grouped into three different stem color categories, namely, green, green with red patch, and red. The majority of the genotypes (42\%) had green with red patch of stem color, while $33 \%$ and $25 \%$ of genotypes had red and green stem colors, respectively. The genotypes were grouped in tototally green $(92 \%)$ and green with red vein $(8 \%)$ leaf colors, while 1 (31\%) genotype had green, $13(36 \%)$ red above green below, and $12(33 \%)$ red petiole colors. Two distinct positions of fruit on the main stem were observed, erect and intermediate. The majority (94\%) of accessions were erected and only $6 \%$ were in an intermediate fruit position on the main stem. Most (81\%) of the genotypes had rough fruit pubescence and $19 \%$ had smooth fruit, $22 \%$ had conspicuous leaf pubescence, and 78\% were glabrous leaf. The 24 landrace okra genotypes collected from Ethiopia were distributed in all categories of qualitative traits.

\subsection{Estimates of Variability Components}

3.3.1. Phenotypic and Genotypic Coefficient of Variations. The estimates of phenotypic and genotypic coefficient of variations were in the range between $4.83 \%$ (days to maturity) and $46.35 \%$ (protein content of seed) and between $3.58 \%$ (days to $50 \%$ emergence) and $46.31 \%$ (protein content of seed), respectively (Table 2 ). The crop phenology (days to $50 \%$ emergence, days to first flowering, days to $50 \%$ flowering, and days to maturity), hundred-seed weight, and biochemical contents (ash content and fat) had less than 10\% for both PCV and GCV. Genotypic coefficient of variations for number of internodes was also less than 10\%. According to [37], PCV and GCV could be categorized as low $(<10 \%)$, moderate (10-20\%), and high (>20\%).

Accordingly, low PCV and GCV values were computed for phenology traits (days to 50\% emergence, days to first flowering, days to $50 \%$ flowering, and days to maturity), hundred-seed weight, and biochemical contents (ash and fat); low estimate of GCV coupled with moderate PCV for number of internodes and [38] low GCV and PCV indicated the existence of limited variability in the genotypes evaluated for the traits showing low genetic variability in the genotypes stock studied. Statistical parameters like PCV, GCV, and ECV were measured, which determine the effectiveness of selection for a particular trait in that genotype [39].

The estimates of GCV and PCV were moderate for stem diameter, leaf length, leaf width, fruit length, number of fruit ridges, number of fruits per plant, number of seeds per pod, and crude fibre, while moderate GCV and high PCV were estimated for plant height and peduncle length. The difference between the values of PCV and GCV was low for the majority of these traits suggesting the genetic potential of the genotypes to correspond to the phenotypic expression of genotypes. Reference [40] also reported that the lower difference between GCV and PCV implies lower influence of environmental factors for the phenotypic expression of traits and selection on the basis of phenotype expression. This might lead to improvement. In addition, the low PCV and GCV values of traits suggest the higher influence of environment on these traits; thus, selection on the phenotypic basis would not be effective for the genetic improvement [41].

Number of branches, internode length, fresh fruit weight, number of mature pods, fruit yield per plant, fruit yield per hectare, seed yield per plant, seed yield per hectare, and seed protein content had high PCV and GCV values $>20 \%$. This may suggest that most of the traits were less influenced by environmental factors and selection based on phenotypic expression of the genotypes could be applied as breeding method to improve the traits. Reference [42] suggested that the high phenotypic and genotypic coefficient of variation is an indication of the less influence of environmental factors on the expression of traits and the higher chance to improve the traits through selection breeding.

3.4. Estimates of Heritability and Genetic Advance. The heritability values ranged between 33.63 and $99.81 \%$, while the GAM value ranged between 4.29 and $95.45 \%$ (Table 2). Lowest $\mathrm{H}^{2}$ and GAM were estimated for days to $50 \%$ emergence, while highest $\mathrm{H}^{2}$ and GAM were estimated for seed protein content. As suggested by [20], heritability values are categorized as low $(<30 \%)$, moderate $(30-60 \%)$, 
TABLE 2: Genetic variability components for 27 traits of 36 okra genotypes evaluated at Melkassa in 2018.

\begin{tabular}{|c|c|c|c|c|c|c|c|c|c|}
\hline Trait & Range & Mean & $\sigma^{2} g$ & $\sigma^{2} \mathrm{p}$ & GCV (\%) & PCV (\%) & $\mathrm{H}^{2}(\%)$ & GA & GAM (\%) \\
\hline Days to $50 \%$ emergence & $7-8$ & 7.63 & 0.07 & 0.22 & 3.58 & 6.18 & 33.63 & 0.33 & 4.29 \\
\hline Days to first flowering & $50-61.5$ & 54.54 & 9.92 & 12.34 & 5.78 & 6.44 & 80.41 & 5.83 & 10.69 \\
\hline Days to $50 \%$ flowering & $54.5-66.5$ & 58.85 & 9.74 & 12.94 & 5.3 & 6.11 & 75.31 & 5.59 & 9.5 \\
\hline Days to maturity & $74-87$ & 79.25 & 10.42 & 14.68 & 4.07 & 4.83 & 70.98 & 5.61 & 7.08 \\
\hline Stem diameter $(\mathrm{cm})$ & $1.27-2.34$ & 1.76 & 0.04 & 0.1 & 11.81 & 17.65 & 44.8 & 0.29 & 16.31 \\
\hline Plant height $(\mathrm{cm})$ & $70.5-162.03$ & 114.16 & 449.98 & 703.53 & 18.58 & 23.23 & 63.96 & 35 & 30.66 \\
\hline Number of branches & $0.7-4.15$ & 2.23 & 0.92 & 1.07 & 43.03 & 46.33 & 86.25 & 1.84 & 82.44 \\
\hline Number of inter nodes & $12.1-20.93$ & 14.83 & 1.82 & 5.18 & 9.09 & 15.34 & 35.11 & 1.65 & 11.11 \\
\hline Inter node length $(\mathrm{cm})$ & $3-10.5$ & 5.33 & 2.18 & 2.85 & 27.71 & 31.66 & 76.6 & 2.67 & 50.04 \\
\hline Leaf length $(\mathrm{cm})$ & $10.5-19$ & 14.41 & 2.17 & 5.85 & 10.23 & 16.78 & 37.14 & 1.85 & 12.86 \\
\hline Leaf width (cm) & $14.84-27.1$ & 20.18 & 6.2 & 14.93 & 12.34 & 19.15 & 41.56 & 3.31 & 16.42 \\
\hline Peduncle length $(\mathrm{cm})$ & $1-3$ & 1.9 & 0.12 & 0.16 & 17.52 & 20.23 & 74.96 & 0.62 & 31.29 \\
\hline Fruit length $(\mathrm{cm})$ & $8.25-22.86$ & 15.45 & 5.99 & 7.66 & 15.84 & 17.92 & 78.1 & 4.46 & 28.88 \\
\hline Number of fruit ridge & $5-9.5$ & 7.06 & 0.64 & 1.05 & 11.3 & 14.49 & 60.85 & 1.28 & 18.19 \\
\hline Fresh fruit weight (g) & $20.82-62.41$ & 34.77 & 80.25 & 110.39 & 25.77 & 30.22 & 72.7 & 15.76 & 45.32 \\
\hline Number of fruit per plant & $19-33.86$ & 0.96 & 14.4 & 21.06 & 13.85 & 16.75 & 68.38 & 6.47 & 23.63 \\
\hline Number of mature pod & $3.5-18.75$ & 9.09 & 8.42 & 11.2 & 31.92 & 36.81 & 75.21 & 5.19 & 57.12 \\
\hline Fruit yield per plant $(\mathrm{kg})$ & $0.57-1.86$ & 0.96 & 0.05 & 0.1 & 23.97 & 32.69 & 53.78 & 0.35 & 36.27 \\
\hline Fruit yield ton $\mathrm{ha}^{-1}$ & $11.69-38.85$ & 20.06 & 20.91 & 43.01 & 22.79 & 32.69 & 48.63 & 6.58 & 32.79 \\
\hline Number of seeds per pod & $62.63-128.17$ & 96.64 & 139.09 & 226.32 & 12.2 & 15.57 & 61.45 & 19.07 & 19.74 \\
\hline Hundred seeds weight (g) & $5.32-8$ & 6.61 & 0.24 & 0.44 & 7.35 & 9.99 & 54.06 & 0.74 & 11.14 \\
\hline Seed yield per plant (g) & $23.95-116.31$ & 58.53 & 391.84 & 562.16 & 33.82 & 40.51 & 69.7 & 34.09 & 58.26 \\
\hline Seed yield per hectare $(\mathrm{kg})$ & $498.9-2423$ & 1219 & 170064.5 & 243990 & 33.82 & 40.51 & 69.7 & 710.27 & 58.25 \\
\hline Total ash (\%) & $3.82-4.96$ & 4.3 & 0.05 & 0.05 & 4.96 & 5.17 & 92.24 & 0.42 & 9.83 \\
\hline Crude fat (\%) & $13.13-17.21$ & 15.35 & 0.57 & 1.08 & 4.94 & 6.76 & 53.31 & 1.14 & 7.44 \\
\hline Crude fiber (\%) & $23.8-37.01$ & 30.37 & 10.53 & 10.99 & 10.69 & 10.92 & 95.78 & 6.55 & 21.57 \\
\hline Total protein $(\%)$ & $4.51-24.79$ & 11.06 & 26.24 & 26.29 & 46.31 & 46.35 & 99.81 & 10.56 & 95.45 \\
\hline
\end{tabular}

$\sigma^{2} \mathrm{~g}$ and $\sigma^{2}$ p represent genotypic and phenotypic variance, respectively; GCV (\%) and PCV (\%) represent genotypic and phenotypic coefficient of variation, respectively; $H^{2}$ is heritability in broad sense; GA and GAM (\%) are genetic advance and genetic advance as percent of mean, respectively.

and high $(>60 \%)$ and GAM values are classified as low $(<10 \%)$, moderate $(10-20 \%)$, and high $(>20 \%)$.

Moderate $\mathrm{H}^{2}$ coupled with low GAM was estimated for days to $50 \%$ emergence and crude fat, and both estimates of $\mathrm{H}^{2}$ and GAM were moderate for stem diameter, number of internodes, leaf length, leaf width, and hundred-seed weight, while high $\mathrm{H}^{2}$ and low GAM were estimated for days to $50 \%$ flowering, days to maturity, and total ash. The estimates of $\mathrm{H}^{2}$ or GAM were either low or moderate for these traits indicating the considerable influence of environment on the expression of the traits. Selection of genotypes based on one season may not be effective to identify best performing genotypes [37]. Moreover, the estimated GCV was low for all these traits except for fruit yield per plant and fruit yield ton $\mathrm{ha}^{-1}$ indicating the high environmental effects on the expression of the traits in genotypes. This confirms that the selection is not rewarding to improve the traits. Reference [18] suggested that GCV together with heritability estimates would give the best picture of the extent of the advance to be expected by selection. High heritability alone does not signify an increased genetic advance; therefore, if GAM is estimated to be low, then the traits are unsuitable for improvement through conventional selection [43]. Moderate $\mathrm{H}^{2}$ and high GAM estimated for fruit yield per plant and fruit yield ton $\mathrm{ha}^{-1}$ indicated that the high environmental effects may be the cause of low $\mathrm{H}^{2}$ but the high GAM suggested that selection may be effective to identify genotypes for high performance [37].
In this study, high heritability was coupled with high GAM for plant height, branch, internod length, fruit length, peduncle length, fresh fruit weight, number of fruits per plant, number of mature pods, seed yield per plant, seed yield per hectare, and fibre and protein content.

Heritability provides evidence for genetic control for the expression of a given trait and phenotypic reliability to predict its breeding value. It also estimates genetic advance that a breeder can expect from selection and which breeding method to adopt [44]. Therefore selection of high performing genotypes is possible for the improvement of these traits. The high heritability would be a close correspondence between the genotypic and phenotypic variations due to relatively small contribution of the environment to the phenotype expression of the trait [45]. Heritability estimates along with genetic advance provide better information than each parameter alone [20]. Reference [46] suggested that selection based on phenotypic performance of genotypes would be effective to improve the traits for which there is high genetic advance as percent of mean coupled with high heritability estimates.

\section{Conclusion}

Generally, the research results indicated the presence of wide genetic variations among studied okra genotypes for fruit yield and nutritional content. There was high 
heritability in most of the traits of the crop. The results suggest that there is a high chance to develop high fruit yield and good nutritional varieties through selection and/ or hybridization.

\section{Data Availability}

The raw data and additional information are available from the corresponding author upon request.

\section{Conflicts of Interest}

The authors declare that there are no conflicts of interest.

\section{Acknowledgments}

The authors are highly grateful to Africa Center of Excellence for Climate Smart Agriculture and Biodiversity Conservation, Haramaya University, for funding this research.

\section{Supplementary Materials}

Mean values of 36 okra genotypes for 27 traits are available under the Supplementary Materials. Supplementary Materials Table 1: mean values of 36 okra genotypes for phenology traits evaluated at Melkassa in 2018. Supplementary Materials Table 2: mean values of 36 okra genotypes for growth traits evaluated at Melkassa in 2018. Supplementary Materials Table 3: mean values of 36 okra genotypes for fruit traits evaluated at Melkassa in 2018. Supplementary Materials Table 4: mean values of 36 okra genotypes for fruit and seed yield traits evaluated at Melkassa in 2018. Supplementary Materials Table 5: mean values of 36 okra genotypes for biochemical traits evaluated at Melkassa in 2018. (Supplementary Materials)

\section{References}

[1] A. Naveed, A. A. Khan, and I. A. Khan, "Generation means analysis of water stress tolerance in okra [Abelmoschus esculentus (L.) Moench]," Pakistan Journal of Botany, vol. 41, no. 1, pp. 195-205, 2009.

[2] B. M. Santos, P. J. Dittmar, S. M. Olson, S. E. Webb, and S. Zhang, Okra Production in Florida, pp. 163-171, University of Florida IFAS extension, Gainesville, FL, USA, 2012.

[3] K. Kamalpreet, P. Mamta, K. Satinder, P. Dharminder, and C. Neena, "Assessment of morphological and molecular diversity among okra [Abelmoschus esculentus (L.) Moench.] germplasm," Académica, vol. 12, no. 21, pp. 3160-3170, 2013.

[4] G. Sousa Ferreira Soares, A. M. S. Assreuy, C. A. Almeida Gadelha et al., "Purification and biological activities of Abelmoschus esculentus seed lectin," The Protein Journal, vol. 31, no. 8, pp. 674-680, 2012.

[5] H. D. Tindall, Vegetables in the Tropics, Macmillan Education Limited, London, UK, 1983.

[6] W. J. Lamont, "Okra A versatile vegetable crop," HortTechnology, vol. 9, no. 2, pp. 179-184, 1999.

[7] A. A. Fajinmi and O. B. Fajinmi, "Incidence of okra mosaic virus at different growth stages of okra plants [Abelmoschus esculentus (L.) Moench] under tropical condition," Journal of
General and Molecular Virology, vol. 2, no. 1, pp. 028-031, 2010.

[8] T. Moekchantuk and P. Kumar, Export Okra Production in Thailand, Intercountry Programme for Vegetable IPM in South \& SE Asia Phase II Food and Agriculture Organization of the United Nations, Bangkok, Thailand, 2004.

[9] A. Shujaat, A. H. Shah, G. Rehmani, A. Habib, N. Hasnian, and S. K.. Sherwani, "Morpho-agronomic characterization of okra [abelmoschusesculentus (L.) Moench]," World Applied Sciences Journal, vol. 31, no. 3, pp. 336-340, 2014.

[10] J. R. Welsh, Fundamentals of Plant Genetics and Breeding, John Wiley \& Sons, New York, NY, USA, 1990.

[11] K. Prakash, M. Pitchaimuthu, and K. V. Ravishankar, "Research Article Assessment of genetic relatedness among okra genotypes [Abelmoschus esculentus (L.) Moench] using RAPD markers," Electronic Journal of Plant Breeding, vol. 2, no. 1, pp. 80-86, 2011.

[12] Y. Mihretu, G. Weyessa, and D. Adugna, "Variability and association of quantitative characters among okra [Abelmoschus esculentus (L.) Moench] collection in South Western," 2014.

[13] Ministry of Agriculture and Natural Resources (MoANR), Crop variety registers issue No. 19:211, Addis Abeba, Ethiopia, 2016.

[14] Melkassa Agricultural Research Center (MARC), Melkassa Agricultural Research Center, Ethiopian Institute of Agricultural Research, Center Profile, Melkassa, Ethiopia, 2008.

[15] International Plant Genetic Resource Institute (IPGRI), Okra Descriptor, Diversity for Development, International Plant Genetic Resource Institute, Rome, Italy, 1991.

[16] Association of Official Analytical Chemists (Aoac), Official methods of Analysis, of AOAC International, Washington, DC, USA, 2000.

[17] SAS Institute, SAS/STAT Guide for Personal Computers, Version 9.0 Editions, SAS Institute Inc., Cary, NC, USA, 2004.

[18] G. W. Burton and E. W. Devane, "Estimating heritability, GCV and PCV in tall Fescue from replicated clonal material," Journal of Agronomy, vol. 45, pp. 171-181, 1953.

[19] D. S. Falconer and F. C. Mackay, An Introduction to Quantitative Genetics, Hall, London. UK, 1996.

[20] H. W. Johnson, H. F. Robinson, and R. E. Comstock, "Genotypic and phenotypic correlations in soybeans and their implications in selection 1," Agronomy Journal, vol. 47, no. 10, pp. 477-483, 1955.

[21] N. Temam, W. Mohamed, and S. Aklilu, "Agro morphological characterization and evaluation of okra [Abelmoschus esculentus (L.) Moench] genotypes for yield and other variability components at Melkassa, Central Ethiopia," MOJ Ecology \& Environmental Sciences, vol. 5, no. 2, p. 80-87, 2020.

[22] D. Muluken, M. Wassu, and G. Endale, "Variability, heritability and genetic advance in Ethiopian okra [abelmoschus esculentus (L.) monech] collections for tender fruit yield and other agro-morphological traits," Journal of Applied Life Sciences International, vol. 4, no. 1, pp. 1-12, 2016.

[23] A. S. Gerrano, "Agronomic performance, nutritional phenotyping and trait associations of okra [Abelmoschus esculentus (L.) Moench] genotypes in South Africa," Rediscovery of Landraces as a Resource for the Future, vol. 69, 2018.

[24] K. K. Tripathi, O. P. Govila, W. Ranjini, and A. Vibha, Biology of Okra [Abelmoschus Esculentus (L.) Moench]. Serious of Crop Specific Biology Document, Ministry of Environment and forests government of India and department of biotechnology ministry of science and technology government of India, Mumbai, India, 2011. 
[25] A. K. Ravat and M. Nirav, "Influence of plant growth regulators on growth, seed yield and seed quality in okra [Abelmoschus esculentus (L.) Moench]. GAO-5 under middle Gujarat condition," InternationalJournal of Agricultural Sciences, vol. 11, no. 1, pp. 51-157, 2015.

[26] C. Sackett, "Fruit and vegetable facts and points. United Fresh Fruit \& Vegetables Association. Washington, DC Characterization of okra [Abelmoschus esculentus (L.) Moench] genotypes for fruit firmness, other horticultural traits and heritability studies," International Journal of Agriculture and Biology, vol. 20, no. 2, pp. 345-352, 1975.

[27] M. A. H. Talukder, M. A. Mannaf, M. K. Alam, M. A. Salam, and M. M. U. Amin, "Influence of sowing time, plant spacing and picking interval on the growth and yield of okra," Pakistan Journal of Biological Sciences, vol. 6, no. 18, pp. 1626-1630, 2003.

[28] B. Tesfa and A. Yosef, "Characterization of okra [Abelmoschus esculentus (L.) Moench] germplasms collected from WesternEthiopia," International Journal of Research in Agriculture andForestry, vol. 3, no. 2, pp. 11-17, 2016.

[29] S. R. Karri and P. Acharyya, "Performance of okra [Abelmoschusesculentus (L.) Moench] cultivars under summer and rainy environments," International Journal of Advance life Science, vol. 2, pp. 16-26, 2012.

[30] K. S. Jindal, D. Arora, and T. R. Ghai, "Variability studies for yield and its contributing traits in okra," Electronic Journal of Plant Breeding, vol. 1, no. 6, pp. 1495-1499, 2010.

[31] A. M. Saleem, M. Amjad, K. Z. Shahbaz, and T. Sahi, "Characterization of okra [Abelmoschus esculentus (L.) Moench] genotypes for fruit firmness, other horticultural traits and heritability studies," International Journal of Agriculture and Biology, vol. 20, no. 2, pp. 345-352, 2017.

[32] C. L. Kalra, J. S. Pruthi, M. S. Teotia, B. L. Raina, B. R. Sharma, and K. S. Nandpuri, "Influence of variety, size, grade and number of ridges of okra on the canned okra (Hibiscus esculentus L.)," Indian Food Packer, vol. 36, no. 2, pp. 53-62, 1982.

[33] A. K. Barnwal, A. K. Pal, A. Tiwari, S. Pal, and A. K. Singh, "Effect of picking stages on fruit and seed development in okra [abelmoschus esculentus (L.) Moench] cultivars kashi pragati and kashi kranti," International Journal of Agriculture Environment \& Biotechnology, vol. 10, no. 6, pp. 695-701, 2017.

[34] S. S. Paththinige, R. M. Ranaweera, and R. M. Fonseka, "Effect of plant spacing on yield and fruit characteristics of okra [Abelmoschusesculentus (L.). Moench]," Tropical Agricultural Research, vol. 20, pp. 336-342, 2008.

[35] O. A. Ashaye, J. O. Akingbala, V. A. Obatolu, and S. B. Fasoyiro, "Improving processing technology and nutritional composition of Nigerian traditional breakfast gruel from corn and Okra," Journal of Agricultural and Food Information, vol. 6, no. 1, pp. 77-87, 2005.

[36] L. A. Bryant, J. Montecalvo, K. S. Morey, and B. Loy, "Processing, functional, and nutritional properties of okra seed products," Journal of Food Science, vol. 53, no. 3, pp. 810-816, 1988.

[37] S. Sivasubramaniah and M. Menon, "Heterosis and in breeding depression in rice. Madras Agriculture Journal 60:1139-1144. Soares GDSF, Assreuy AMS, de Almeida GCA, de Morais GV, Delatorre P, da Conceiçao Simoes R, Cavada BS, Leite JF, Nagano CS, Pinto NV, Pessoa HDLF (2012). Purification and biological activities of Abelmoschus esculentus seed lectin," The Protein Journal, vol. 31, no. 8, pp. 674-680, 1973.

[38] N. Singh, D. K. Singh, U. C. Sati, M. Rawat, and P. Pandey, "Genetic analysis studies in okra [Abelmoschus esculentus (L.)
Moench]," International Journal of Pure \& Applied Bioscience, vol. 5, no. 4, pp. 361-367, 2017.

[39] A. M. Azimi, S. Marker, and I. Bhattacharjee, "Genotypic and phenotypic variability and correlation analysis for yield and its components in late sown wheat (Triticum aestivum L.)," Journal of Pharmacognosy and Phytochemistry, vol. 6, no. 4, pp. 167-173, 2017.

[40] B. Anteneh, "Characterization and evaluation of indigenous and exotic okra [Abelmoschus Esculentus (L.) Moench] genotypes for yield and yield related traits at dire dawa, Eastern Ethiopia," MSc Thesis, Haramaya University, Haramaya, Ethiopia, 2017.

[41] A. A. Ehab, Y. A. Mohamed, and M. M. Ali, "Genetic behaviour of families selected from some local okra [Abelmoschus esculentus (L.) Moench] populations in Egypt," Plant Breeding Biotechnology, vol. 1, no. 4, pp. 396-405, 2013.

[42] B. Swati, N. Reena, R. Meenakshi, and P. K. Jain, "Genetic variability in okra [Abelmoschus esculentus (L.). Moench]," An International Quarterly Journal of Environmental Sciences, vol. 6, pp. 153-156, 2014.

[43] R. Govindarasu, M. Rathinam, and P. Sivasubramanian, "Genetic variability in sesame (Sesamum indicum L.)," Madras Agriculture Journal, vol. 78, no. 1-3, pp. 450-452, 1990.

[44] M. Z. Ullah, M. J. Hasan, A. Z. M. K. A. Chowdhury, A. I. Saki, and A. H. M. A. Rahman, "genetic variability and correlation in exotic cucumber (Cucumis sativus L.) varieties," Bangladesh Journal of Plant Breeding and Genetics, vol. 25, no. 1, pp. 17-23, 2012.

[45] N. Singh, D. K. Singh, U. C. Sati, M. Rawat, and P. Pandey, "GeneticAnalysis studies in okra [Abelmoschus esculentus (L.) Moench]," International Journal of Pure and Applied Bioscience, vol. 5, no. 4, pp. 361-367, 2017.

[46] K. M. Phani, B. A. Hameedunnisa, R. Manohar, and N. S. Kumar, "Estimation of heritability and genetic advance in okra [Abelmoschusesculentus (L.) Moench.]," Plant Archives, vol. 15, no. 1, pp. 489-491, 2015. 